\title{
KOMUNIKASI DALAM DIFUSI INOVASI KERAJINAN ENCENG GONDOK DI DESA TUNTANG, KABUPATEN SEMARANG
}

\author{
Kharisma Ayu Febriana, Yuliyanto Budi Setiawan \\ (kharisma@ftik.usm.ac.id; yuli@usm.ac.id) \\ (Pengajar Jurusan Ilmu Komunikasi Universitas Semarang)
}

\begin{abstract}
Water hyacinth plants for most residents in the village Tuntang considered a weed in large amounts. Water hyacinth lead to silting in waters such as lakes and ponds, but the diffusion of innovation, a lot of business opportunities that can be produced from water hyacinth handicraft businesses. Villagers Tuntang made of water hyacinth as a craft material that has a high value ekomoni. The method used is qualitative descriptive with case study strategy in the village Tuntang. The result through interpersonal communication to make success in the diffusion process of water hyacinth handicraft innovation for residents in the village Tuntang, Semarang regency.
\end{abstract}

Kata Kunci : Komunikasi, Difusi Inovasi, Enceng gondok

\section{Pendahuluan}

Desa Tuntang menjadi pelopor program pengelolaan enceng gondok sebagai alat perlengkapan rumah tangga multifungsi yang dirintis mulai dari tahun 2007. Keberhasilan warga Desa Tuntang dalam mengkomunikasikan inovasi inilah, menciptakan pembaruan yang menarik untuk dilihat secara lebih dekat. Bagaimana warga mengkomunikasikan inovasi baru dengan komunikasi interpersonal dan komunikasi kelompok, sehingga berhasil mengubah persepsi warga yang sebelumnya melihat enceng gondok sebagai tanaman gulma, namun kini dijadikan sebagai kerajinan yang dapat meningkatkan taraf perekonomian warga. Tanaman enceng gondok banyak dikanal orang merupakan gulma bagi tanaman di sawah. Selain gulma dalam jumlah yang besar, enceng gondok akan mengakibatkan pendangkalan pada perairan seperti danau dan kolam. Tetapi dengan difusi inovasi, banyak peluang usaha yang bisa dihasilkan dari bisnis kerajinan enceng gondok. Enceng gondok merupakan serat alam yang ramah lingkungan sehingga aman untuk bahan kerajinan dan menjadi tren bisnis di masyarakat. Dari kerajinan berupa sandal, tas, dompet, perak-pernik perhiasan enceng gondok serta furniture dapat dibuat dari enceng gondok.

Edukasi dan informasi yang diberikan komunikator kepada warga Desa Tuntang merupakan suatu wujud komunikasi interpersonal dan komunikasi kelompok sehingga efektif dalam meningkatkan partisipasi warga Desa Tuntang untuk ikut melakukan suatu difusi inovasi dengan mengolah gulma menjadi kerajinan yang menarik dan memiliki nilai ekonomi. Oleh karena itu, dalam penelitian ini akan dilakukan bagaimana komunikator mengkomunikasikan kepada warga dalam proses difusi inovasi di Desa Tuntang. Kemudian agar diketahui faktor-faktor pendorong dan penghambatnya, sehingga terjadi perubahan masyarakat bersedia melakukan inovasi baru untuk 
berpartisipasi dan mampu menerima inovasi.

Komunikasi yang dilakukan ini diharapkan akan terjadinya perubahan sosial. Pada komunikasi interpersonal dan komunikasi kelompok dalam proses difusi inovasi biasanya pesan-pesan yang disampaikan merupakan ide-ide baru, penyampaian ide-ide baru ini bertujuan melakukan perubahan sosial dan pembangunan bagi warga desa. Permasalahan yang akan diselesaikan adalah bagaimana komunikasi yang terjalin antara komunikator dan komunikan dalam keberhasilan proses difusi inovasi di desa Tuntang. Hal ini untuk mengetahui bagaiama komunikasi komunikator kepada komunikan dalam proses difusi inovasi sehingga dapat mendorong partisipasi masyarakat dalam mengelola tanaman gulma menjadi barang kerajinan yang memiliki nilai ekonomi sehingga warga desa Tuntang mengalami perubahan pola pikir dan peningkatan ekonomi.

Model difusi inovasi digunakan untuk pendekatan dalam komunikasi pembangunan, terutama di negara berkembang seperti Indonesia atau dunia ketiga. Tokohnya Everett $M$. Rogers mendefinisikan difusi sebagai proses dimana suatu inovasi dikomunikasikan melalui saluran tertentu dalam jangka waktu tertentu dari para anggota suatu sistem sosial.

Difusi adalah suatu jenis khusus komunikasi yang berkaitan dengan penyebaran pesan-pesan sebagai ide baru, sedangkan komunikasi didefinisikan sebagai proses di mana para pelakunya menciptakan informasi dan saling bertukar informasi tersebut untuk mencapai pengertian bersama. Didalam pesan itu terdapat keermasaan (newness) yang memberikan ciri khusus kepada difusi yang menyangkut ketakpastian (uncertainty). Derajat ketidak pastian seseorang akan dapat dikurangi dengan jalan memperoleh informasi. Sedangkan Inovasi adalah suatu ide, karya atau objek yang dianggap serta dirasakan oleh anggota suatu sistem sosial yang menentukan tingkat adopsi. Tingkat adopsi meliputi keuntungan relatif, kesesuaian, kerumitan, kemungkinan di coba, dan kemungkinan diamati.

Everett M Rogers dan Floyd G. Shoemaker mengemukakan bahwa teori difusi inovasi dalam prosesnya ada 4 (empat) tahap, yaitu:

a. Pengetahuan: kesadaran individu akan adanya inovasi dan pemahaman tertentu tentang bagaimana inovasi tersebut berfungsi.

b. Persuasi: individu membentuk sikap setuju atau tidak setuju terhadap inovasi.

c. Keputusan: individu melibatkan diri pada aktivitas yang mengarah pada pilihan untuk menerima atau menolak inovasi.

d. Konfirmasi: individu mencari penguatan (dukungan) terhadap keputusan yang telah dibuatnya, tapi ia mungkin berbalik keputusan jika ia memperoleh isi pernyataan peryantaan yang bertentangan.

Dalam proses difusi inovasi, komunikasi memiliki peranan penting menuju perubahan sosial sesuai dengan yang dikehendaki. Rogers dan Floyed Shoemaker (1987) menegaskan bahwa difusi merupakan tipe komunikasi khusus, yaitu mengkomunikasikan inovasi. Ini berarti kajian difusi merupakan bagian kajian komunikasi yang berkaitan dengan gagasan-gagasan baru, sedangkan pengkajian komunikasi meliputi semua bentuk pesan. Jadi, jika yang dikomunikasikan bukan produk inovasi, maka kurang lazim disebut sebagai difusi.

Teori difusi inovasi sangat penting dihubungkan dengan penelitian efek komunikasi. Dalam hal ini 
penekannya adalah efek komunikasi yaitu kemampuan pesan media dan opinion leader untuk menciptakan pengetahuan, ide, penemuan baru, dan membujuk sasaran untuk mengadopsi inovasi tersebut.

$$
\text { Komunikasi Interpersonal, }
$$

menurut Muhammad (1995:159)

komunikasi interpersonal atau komunikasi antarpribadi merupakan proses pengiriman dan penerimaan pesan-pesan antara dua orang atau diantara sekelompok kecil orang dengan beberapa efek dan beberapa umpan balik seketika. Komunikasi interpersonal merupakan komunikasi didalam diri sendiri, didalam diri manusia terdapat komponen-komponen komunikasi seperti sumber, pesan, saluran penerima dan balikan. Pesan mulai dan berakhir dalam diri individu masing-masing. Komunikasi ini sering terjadi dalam kehidupan sehari-hari, misalnya percakapan seseorang ayah dengan anak, sepasang suami istri, guru dengan murid, dan lain sebagainya. Dalam definisi ini setiap komunikasi baru dipandang dan dijelaskan sebagai bahan-bahan yang teritegrasi dalam tindakan komunikasi antarpribadi (Devito, 1997: 231).

Pentingnya suatu komunikasi interpersonal karena prosesnya memungkinkan berlangsung secara dialogis, dimana bentuk komunikasi antarpribadi menunjukkan terjadinya interaksi. Mereka yang terlibat dalam komunikasi bentuk ini berfungsi ganda, masing-masing menjadi pembicara dan pendengar secara bergantian. Dalam proses komunikasi dialogis nampak adanya upaya dari para pelaku komunikasi untuk terjadinya pergantian bersama (mutual understanding) dan empati. Oleh karena itu, komunikasi interpersonal dibandingkan dengan komunikasi lainnya, dinilai paling ampuh dalam kegiatan mengubah sikap, kepercayaan, opini dan perilaku komunikan.

Kemampuan dalam mengubah sikap, kepercayaan, opini dan perilaku komunikan itulah, maka bentuk komunikasi interpersonal seringkali digunakan untuk menyampaikan komunikasi persuasif (persuasive communication) yakni suatu teknik komunikasi secara psikologis manusiawi yang sifatnya halus, luwes berupa ajakan, bujukan atau rayuan. Dengan demikian, setiap pelaku komunikasi akan melakukan empat tindakan yaitu membentuk, menyampaikan, menerima dan mengolah pesan. Keempat tindakan tersebut lazimnya berlangung secara berurutan dan membentuk pesan untuk diartikan sebagai menciptakan ide atau gagasan dengan tujuan tertentu.

Mengkaji komunikasi sebagai suatu proses menurut Effendy (2000: 113) melihat proses komunikasi dari dua perspektif, yaitu perspektif psikologis dan perspektif mekanistik. Proses komunikasi antarpribadi atau komunikasi interpersonal didalamnya terdapat arus komunikasi yang sirkuler atau berputar. Untuk dapat mengetahui komponen-komponen yang terlibat dalam komunikasi antarpribadi dapat dijelaskan melalui model komunikasi interpersonal.

\section{Metodologi Penelitian}

Jenis penelitian yang dipergunakan adalah penelitian kualitatif diskriptif, dengan strategi studi kasus di Desa Tuntang, terkait dengan komunikasi dan difusi inovasi dalam kerajinan enceng gondok. Salah satu definisi mengenai metode penelitian kualitatif adalah sebagai prosedur penelitian yang menghasilkan data deskriptif berupa kata-kata tertulis atau lisan dari orang-orang dan perilaku 
yang dapat diamati (Bogdan et al. 2002).

Mulyana (2002: 20) menjelaskan studi kasus adalah uraian dan penjelasan komprehensif mengenai berbagai aspek seorang individu, suatu kelompok, suatu organisasi (komunitas), suatu program, atau suatu situasi sosial. Strategi studi kasus dalam penelitian ini merupakan studi kasus tunggal, karena penelitian diarahkan pada satu karakteristik. Sasaran adalah sejumlah pribadi, yaitu warga dusun Tuntang yang mengalami difusi inovasi.

Suatu penelitian disebut studi kasus tunggal, bilamana penelitian tersebut terarah satu karakteristik. Artinya penelitian tersebut dilakukan pada satu sasaran. Meskipun penelitian dilakukan (beberapa tempat, kelompok, atau sejumlah pribadi), kalau sasaran tersebut memiliki karakter yang sama atau seragam, maka penelitian tersebut tetap merupakan studi kasus tunggal (Sutopo, 2002).

Lebih khusus lagi penelitian studi kasus tunggal ini menggunakan jenis penelitian terpancang, karena sudah dipilih dan ditentukan variabel yang menjadi fokus utamanya, yaitu komunikasi warga desa Tuntang dalam kerajinan enceng gondok, dengan mengambil kasus pengolahan gulma enceng gondong menjadi bahan kerajinan yang bermanfaat dan memiliki nilai jual, menurut Yin (2000:42) desain terpancang merupakan suatu perangkat penting guna memfokuskan studi kasus. Selanjutnya menurut Sutopo (2002:31) dalam penelitian kualitatif studi kasus mengarah pada pendeskripsian secara rinci dan mendalam mengenai potret kondisi tentang apa yang sebenarnya terjadi menurut apa adanya di lapangan studinya.

Sumber data utama dalam penelitian kualitatif ialah kata-kata, dan tindakan, selebihnya adalah data tambahan. Data atau informasi yang diperlukan dan dikaji merupakan data kualitatif. Informasi digali dari berbagai sumber data, dan jenis sumber data yang dipergunakan dalam penelitian ini yakni informan atau nara sumber, tempat dan peristiwa atau aktivitas terdiri dari lingkungan kegiatan program pembuat enceng gondok di Desa Tuntang. Selai itu juga dengan arsip dan dokumen resmi mengenai partisipasi peserta program pembuatan enceng gondok di Desa Tuntang.

\begin{tabular}{llr} 
Teknik & \multicolumn{1}{c}{ sampling } & yang \\
digunakan & adalah & "purposive \\
sampling". & Penelitian & kualitatif
\end{tabular}
lazimnya menggunakan teknik sampling yang bersifat selektif, disesuaikan dengan keperluan. Cuplikan dalam penelitian kualitatif sering juga dinyatakan sebagai internal sampling yang berlawanan sifatnya dengan cuplikan dalam penelitian kualitatif, yang dinyatakan sebagai external sampling. Sampel lebih bersifat mewakili informasinya daripada mewakili populasinya karena dalam penelitian kualitatif ini cenderung untuk tidak menggeneralisasikan populasi (Bodgan et al. 2002)

Teknik pengumpulan data, Sesuai dengan bentuk penelitian kualitatif dan jenis sumber data yang dimanfaatkan, maka teknik pengumpulan data yang akan digunakan dalam penelitian ini adalah penelitian lapangan (research field) yakni observasi, wawancara mendalam (indepth interviewing), arsip dan dokumen lain yang terkait

Teknik analisis data menurut Moleong (2005:85) menjelaskan analisis data merupakan proses mengorganisasikan dan mengurutkan data ke dalam pola, kategori, dan satuan uraian dasar sehingga dapat ditemukan 
tema dan dirumuskan hipotesis kerja seperti yang disarankan oleh data. Dalam penelitian ini metode yang digunakan adalah analisis data interaktif (interaktive model of analysis) dari Miles dan Huberman yang meliputi pengumpulan data, reduksi data, sajian data, dan penarikan kesimpulan.

\section{Hasil Penelitian Dan Pembahasan}

\section{Profil Desa Tuntang}

Awal mula munculnya pengrajin di desa Tuntang Kabupaten Semarang karena keresahan salah seorang warga yang mengetahui bahwa enceng gondog disebut-sebut sebagai penyebab utama kerusakan alam yang terjadi di Rawa Pening. Rawa Pening terletak di Jawa Tengah tepatnya di wilayah Kabupaten Semarang. Tanaman gulma itu merusakan kelestarian alam diantaranya merusak keramba budidaya ikan masyarakat yang memanfaatkan rawa, akar dan batang tanaman enceng gondog menyilitkan laju, dan menyulitkan para penjaring ikan di rawa pening. Dari situ salah seorang warga yakni ibu Aryani berinisiatif mengolah tanaman gumla menjadi sesuatu yang lebih bermanfaat dan memiliki nilai guna.

Bukan hal yang mudah untuk
menyadarkan dan memberikan
pengarahan kepada warga sekitar bahwa
tanaman enceng gondok yang di anggap
gulma ini dapat diolah menjadi sesuatu
yang lebih bermanfaat dan memiliki
nilai ekonomis. Aryani dan dibantu
rekannya Haryani awalnya
mengkomunikasikan dengan datang
langsung ke rumah-rumah warga. Tak
jarang juga mengadakan pertemuan di
balai desa untuk memberikan
penyuluhan kepada warga tentang
tanaman enceng gondok yang dapat
diolah menjadi barang kerajinan yang

unik dan menarik. Meski awalnya sering mendapat penolakan dari warga, namun seiring berjalannya waktu banyak warga yang mau belajar di balai desa tentang bagaimana cara membuat kerajinan dari enceng gondok, bahkan tak jarang warga yang datang langsung ke rumah ibu Aryani untuk belajar enceng gondok.

Proses pembuatan kerajian enceng gondok diawali dengan usaha pemanenan enceng gondog dilakukan oleh beberapa warga dengan mengumpulkan tanaman enceng gondog kemudian dikeringkan terlebih dahulu, baru setelah benar-benar kering batang enceng gondok dianyam. Biasanya, di tangan pembeli, enceng gondok diolah lagi menjadi produk jadi. warga membuat kerajinan setengah jadi, hanya berbentuk anyaman. Nanti, para agen yang mengolah lagi menjadi barang kerajinan jadi. Barang jadi yang dimaksud, seperti kotak tisu, tirai, tas, sandal, bantal, souvenir, tudung saji, hingga menjadi barang fungsional semacam meja dan kursi.

Sentra kerajinan eceng gondok di Desa Tuntang, Kabupaten Semarang, pembeli yang datang bukan hanya warga Semarang dan sekitarnya, tetapi juga dari luar daerah. Lantaran banyak peminat, para perajin tidak pernah sepi orderan. Salah seorang perajin, Mulyani menuturkan, "saya rutin mengirimkan hasil anyaman enceng gondok ke galeri ibu Aryani untuk diolah menjadi produk kerajinan, " tuturnya. Pengrajin lain Wati menambahkan, "Namun, tak jarang pembeli dari luar daerah bahkan luar negri membeli anyaman mentah, turis asing biasanya menyukai kerajinan semacam ini, karena bertema back to nature. Bahkan jika sudah menjadi 
sampah produk kerajinan ini tidak akan merusak alam".

\section{Proses Difusi Inovasi}

Difusi merupakan suatu komunikasi yang berkaitan dengan penyebaran pesan-pesan sebagai ide baru. Difusi inovasi adalah proses sosial yang mengomunikasikan informasi tentang ide baru yang dipandang secara subjektif. Makna inovasi dengan demikian perlahan-lahan dikembangkan melalui sebuah proses konstruksi sosial. Dalam hal pengelolaan enceng gondok, proses difusi terjadi saat para pengelola mengkomunikasikan kepada warga tentang pengelolaan batang enceng gondok yang setelah dikeringkan dapat dianyam menjadi berbagai bahan kerajinan yang multi fungsi. Hal yang tidak mudak dalam mengubah pola pikir warga mengganggap enceng gondok sebagai gulma tanaman penggangu bagi warga, namun kini menjadi bahan yang bermanfaat dan memiliki nilai guna yang tinggi. Karena dibutuhkan komunikasi yang baik antara pengelola dengan warga masyarakat untuk mau mendengarkan penyuluhan dan belajar membuat bahan kerajinan enceng gondok. Salah seorang pengrajin Sri menjelaskan, "Awalnya saya enggan untuk mengikuti kegiatan ini karena tidak tahu manfaatnya, namun setelah tahu manfaatnya saya justru mendaftarkan diri sebagai anggota dalam kegiatan ini,". Pendapat serupa dituturkan Wari sebagai buruh cuci, yang awalnya menganggap kegiatan ini menyita waktunya, namun justru dapat dijadikan pekerjaan sampingan di sore dan malam hari dengan menganyam enceng gondok.

Inovasi yang dipandang oleh penerima sebagai inovasi yang mempunyai manfaat relatif, kesesuaian, kemampuan untuk dicoba, kemampuan dapat dilihat yang jauh lebih besar, dan tingkat kerumitan yang lebih rendah akan lebih cepat diadopsi daripada inovasi-inovasi lainnya. Hal yang tidak sukar bagi warga untuk belajar mengolah limbang enceng gondok untuk dijadikan bahan kerajinan yang unik. Mulyani (pengelola kelompok pengrajin enceng gondok) menjelaskan proses produksinya yang pertama-tama inovasi ini dimulai dengan warga panen enceng gondok di rawa untuk diambil batangnya, setelah itu proses pengeringan dengan di jemur di bawah terik matahari beberapa hari hingga kering, setelah batang enceng gondok kering baru proses penganyaman dengan dikepang lima ruas. Cara pengepangan benar-benar harus kencang dan rapi agar hasil kerajinannya benar-benar baik. Dari hasil anyaman di desain lagi untuk hasil kerajinan. Warga dapat membawanya ke pengelola seperti ibu Aryani atau ibu Haryani untuk dijual secara mentah, dan Haryani yang mengolahnya atau warga sendiri yang langsung mengolahnya langsung menjadi berbagai produk seperti sandal, tempat tisu, sarung bantal kursi, taplak meja, hiasan dinding, meja, hingga kursi, dan lain sebagainya.

Rogers (1987) menyebutkan adanya tahapan dalam difusi inovasi yakni, tahap pengetahuan, persuasi, keputusan, implementasi :

a. Tahap Pengetahuan (Knowledge)

Tahap ini merupakan tahap penyebaran informasi tentang inovasi baru, dalam tahap ini kesadaran individu akan mencari atau membentuk pengertian inovasi dan tentang bagaimana inovasi tersebut berfungsi. Rogers mengatakan ada tiga macam pengetahuan yang dicari masyarakat dalam tahapan ini, yakni kesadaran bahwa inovasi itu ada, pengetahuan 
akan penggunaan inovasi, dan pengetahuan yang mendasari bagaimana fungsi inovasi tersebut bekerja. Pada tahap pengetahuan para pengelola pengrajin enceng gondok memberikan informasi kepada warga di desa Tuntang tentang inovasi baru yakni mengubah tanaman gulma enceng gondok menjadi bahan kerajinan dengan nilai ekonomi yang tinggi. Pengurus pengrajin enceng gondok awalnya mengumpulkan warga ke balai desa setiap sebulan dua atau tiga kali dengan memberikan penyuluhan bagaimana proses pengelolaan enceng gondok menjadi bahan kerajinan seperti tempat tisu, sandal, taplak meja, kursi, meja, dan sebagainya. Dalam proses penjelasan inovasi baru dibuat sesederhana mungkin ditujukan warga cepat paham tentang bagaimana proses pengolahan limbah menjadi bahan kerajinan adalah sesuatu yang mudah dan diharapkan warga tertarik hingga mau belajar membuatnya.

b. Tahap Persuasi

Dalam tahapan ini individu membentuk sikap atau memiliki sifat yang menyetujui atau tidak menyetujui inovasi tersebut. Dalam tahap persuasi ini, individu akan mencari tahu lebih dalam informasi tentang inovasi baru tersebut dan keuntungan menggunakan informasi tersebut. Pada tahap persuasi, aktifitas mental yang terjadi akan memengaruhi afektif. Haryani menjelaskan, "Pada tahap persuasi para pengelola kerajinan enceng gondok menggunakan pendekatan komunikasi interpersonal dengan pendekatan dari hati ke hati dan kekeluargaan untuk mengajak warga desa Tuntang ikut bergabung menjadi pengrajin enceng gondok". Awalnya menggunakan pendekatan kekeluargaan dimana warga dikumpulkan di balai desa untuk diberikan pengarahan agar mau menjadi pengrajin enceng gondok. Selain itu, pengelola kerajinan juga datang ke rumah-rumah warga untuk melakukan pendekatan secara personal kepada warga dengan memberikan pengarahan tentang manfaat serta cara pengelolaan enceng gondok. Komunikasi interpersonal dengan datang ke rumahrumah warga dianggap efektif dalam melakukan tahap persuasi pengelolaan enceng gondok menjadi bahan yang bermanfaat dan memiliki nilai ekonomi. Dan tahap terakhir adalah tahap pengambilan kepuutusan.

c. Tahap Pengambilan Keputusan

Di tahapan ini individu terlibat dalam aktivitas yang membawa pada suatu pilihan untuk mengadopsi inovasi tersebut atau tidak sama sekali. Adopsi adalah keputusan untuk menggunakan sepenuhnya ide baru sebagai cara tindak yang paling baik. Ada beberapa faktor yang mempengaruhi proses keputusan inovasi warga desa Tuntang untuk mau menjadi pengrajin enceng gondok, yakni adanya praktik sebelumnya yang dilakukan para pengurus kerajinan kepada warga desa Tuntang, pelatihan dalam pembuatan kerajinan enceng gondok di buat di balai desa dan di rumah-rumah warga. Selanjutnya warga merasa membutuhkan kerajinan ini karena memiliki manfaat dan nilai ekonomi bagi warga. Inovasi baru bagi warga karena bahan dasarnya adanya tanaman yang dianggap gulma selama ini oleh warga, namun setelah mendapatkan sosialisasi dari pengelola kerajinan warga merasa bahwa enceng gondok adalah tanaman yang memiliki nilai ekonomi yang cukup baik bagi warga.

d. Tahapan Implementasi

Implementasi dalam hal ini adalah partisipasi atau keikutsertaan warga untuk mau panen enceng gondok, proses pengeringan, sampai anyaman dan ikut membuat bahan kerajinan enceng gondok menjadi 
produk kerajinan yang unik seperti hiasan dinding, sandal, taplak meja, kursi, meja, dan lain sebagainya.

\section{Komunikasi Interpersonal}

Komunikasi interpersonal tidak kalah dengan menggunakan saluran komunikasi massa dalam menyebarkan informasi tentang inovasi. Hal itu dikarenakan diadopsi tidaknya inovasi baru terkait dengan masalah resiko dan ketidakpastian. Disinilah letak pentingnya komunikasi antarpribadi. Karena komunikasi interpersonal memiliki keunggulan dengan penyebaran informasi dalam inovasi baru dilakukan oleh orang sudah dikenal dan dipercayai lebih awal atau orang yang mungkin sudah berhasil mengadopsi inovasi baru itu sendiri, dan juga orang yang memiliki kredibilitas untuk memberi saran mengenai inovasi tersebut.

Salah seorang warga yang menajadi tokoh pengelola kerajinan enceng gondok yakni Aryani merupakan sosok wanita yang cukup disegani warga sekitar, pembawaannya yang sabar dan pekerja keras menjadikannya sukses dalam membangun kerajinan enceng gondok, bahkan ia memiliki galeri sendiri dan produk kerajinannya tidak hanya dikirim ke berbagai daerah namum hingga kebergai negara di luar negri. Ibu Aryani mengajar beberapa rekan kerjanya untuk bekerjasama dalam memberikan pengarahan ke warga desa Tuntang dengan pendekatan personal di balai desa, bahkan datang ke rumahrumah warga dengan melakukan komunikasi interpersonal, hal ini dirasa sangat efektif dalam mendorong warga untuk mau ikut menjadi pengrajin enceng gondok.

Ibu Aryani menuturkan, "Awalnya tidak mudah memberikan hal baru kepada warga desa Tuntang dimana sebagian besar warga menggangap bahwa enceng gondok adalah gulma taman penggangu, menjadi bahan kerajinan yang bermanfaat". Dengan pendekatan komunikasi interpersonal, membangun adanya kepercayaan, ngobrol dari hati ke hati, dan memberikan pemahaman secara pelan-pelan kepada warga tentang manfaat dari pengelolaan enceng gondok, hingga akhirnya mau untuk belajar membuat kerajinan enceng gondok. komunikasi interpersonal menjadi begitu sangat berpengaruh karena komunikasi ini dirasa akan lebih optimal digunakan pada tahap persuasi. Khususnya di negara yang belum maju seperti Indonesia kekuatan komunikasi interpersonal masih dinilai lebih penting dalam tahap pengetahuan. Hal ini disebabkan karena kurangnya media massa yang dapat dijangkau masyarakat terutama di pedesaan, tingginya tingkat buta huruf penduduk. Karena hal-hal tersebut, saluran komunikasi interpersonal terutama yang bersifat personal dinilai saluran komunikasi yang efektif dalam penyebaran inovasi baru kepada warga desa Tuntang.

\section{Kesimpulan}

Pada dasarnya penelitian ini bertujuan untuk mengetahui bagaiama komunikasi yang dilakukan dalam proses difusi inovasi sehingga dapat mendorong partisipasi masyarakat dalam mengelola tanaman gulma menjadi barang kerajinan yang memiliki nilai ekonomi bagi warga desa Tuntang.

Berdasarkan penelitian yang telah dilakukan, maka peneliti mendapat beberapa kesimpulan sebagai berikut :

Difusi inovasi adalah proses sosial yang mengomunikasikan informasi tentang ide baru yang dipandang secara subjektif. Makna inovasi dengan demikian perlahan-lahan 
dikembangkan melalui sebuah proses konstruksi sosial. Dalam hal pengelolaan enceng gondok, proses difusi terjadi saat para pengelola mengkomunikasikan kepada warga tentang pengelolaan batang enceng gondok yang setelah dikeringkan dapat dianyam menjadi berbagai bahan kerajinan yang multi fungsi. Hal yang tidak mudak dalam mengubah pola pikir warga mengganggap enceng gondok sebagai gulma tanaman penggangu bagi warga, namun kini menjadi bahan yang bermanfaat dan memiliki nilai guna yang tinggi. Karena dibutuhkan komunikasi yang baik antara pengelola dengan warga masyarakat untuk mau mendengarkan penyuluhan dan belajar membuat bahan kerajinan enceng gondok. Rogers (1987) menyebutkan adanya tahapan dalam difusi inovasi yakni, tahap pengetahuan, persuasi, keputusan, implementasi :

Pada tahap pengetahuan para pengelola pengrajin enceng gondok memberikan informasi kepada warga di desa Tuntang tentang inovasi baru yakni mengubah tanaman gulma enceng gondok menjadi bahan kerajinan dengan nilai ekonomi yang tinggi. Selanjutnya tahap persuasi dalam tahap persuasi ini, individu akan mencari tahu lebih dalam informasi tentang inovasi baru tersebut dan keuntungan menggunakan informasi tersebut. Pada tahap persuasi para pengelola kerajinan enceng gondok menggunakan pendekatan komunikasi interpersonal dengan pendekatan dari hati ke hati dan kekeluargaan untuk mengajak warga desa Tuntang ikut bergabung menjadi pengrajin enceng gondok.

Tahap Pengambilan Keputusan di tahapan ini individu terlibat dalam aktivitas yang membawa pada suatu pilihan untuk mengadopsi inovasi tersebut atau tidak sama sekali. Ada beberapa faktor yang mempengaruhi proses keputusan inovasi warga desa Tuntang untuk mau menjadi pengrajin enceng gondok, yakni adanya praktik sebelumnya yang dilakukan para pengurus kerajinan kepada warga desa Tuntang, pelatihan dalam pembuatan kerajinan enceng gondok di buat di balai desa dan di rumah-rumah warga. Selanjutnya warga merasa membutuhkan kerajinan ini karena memiliki manfaat dan nilai ekonomi bagi warga. Terakhir adalah implementasi dalam hal ini adalah partisipasi atau keikutsertaan warga untuk mau panen enceng gondok, proses pengeringan, sampai anyaman dan ikut membuat bahan kerajinan enceng gondok menjadi produk kerajinan yang unik seperti hiasan dinding, sandal, taplak meja, kursi, meja, dan lain sebagainya.

Komunikasi interpersonal sangat efektif dalam menyebarkan difusi inovasi kerajinan enceng gondok karena komunikasi ini memiliki keunggulan dengan penyebaran informasi dalam inovasi baru dilakukan oleh orang sudah dikenal dan dipercayai lebih awal atau orang yang sudah berhasil mengadopsi inovasi baru itu sendiri, dan juga orang yang memiliki kredibilitas untuk memberi saran mengenai inovasi tersebut.

Salah seorang warga yang menajadi tokoh pengelola kerajinan enceng gondok yakni Aryani merupakan sosok wanita yang cukup disegani warga sekitar, pembawaannya yang sabar dan pekerja keras menjadikannya sukses dalam membangun kerajinan enceng gondok, bahkan ia memiliki galeri sendiri dan produk kerajinannya tidak hanya dikirim ke berbagai daerah namum hingga kebergai negara di luar negri. Ibu Aryani mengajar beberapa rekan kerjanya untuk bekerjasama dalam memberikan pengarahan ke warga desa 
Tuntang dengan pendekatan personal di balai desa, bahkan datang ke rumahrumah warga dengan melakukan komunikasi interpersonal, hal ini dirasa sangat efektif dalam mendorong warga yang akhirnya mau ikut menjadi pengrajin enceng gondok.

\section{Daftar Pustaka}

Bogdan, Robert, et. al., "Introduction To Qualitative Research Methods: A Phenomenological Approach To The Social Sciences", terj. Furchan, Arief. (2002). Pengantar Metode Penelitian Kualitatif: Suatu Pendekatan Fenomenologis Terhadap IlmuIlmu Social. Surabaya: Usaha Nasional.

Devito, Joseph. (1997). Komunikasi Antarpribadi. Edisi Kelima. Jakarta : Profesional Book

Effendy, Onong Uchyana. (2000). Ilmu, Toeri dan Filsafat Komunikasi. Citra Aditya Bakti.
Moleong, Lexy J. (2005). Metologi Penelitian Kualitatif. Bandung : remaja Rosda Karya

Muhammad, Arni. (1995). Komunikasi Organisasi. Jakarta: Bumi Aksara.

Mulyana, D. (2002). Metodologi Penelitian Kualitatif. Paradigma Baru Ilmu Komunikasi dan Ilmu Sosial lainnya. Bandung : Rosdakarya.

Rogers, Everett M. (1987). Diffusion of Innovations. London: The Free Press.

Sutopo. (2002). Metedeologi Penelitian Kualitatif. Surakarta: UNS.Press

Yin, K, Robert. (2000). Studi Kasus : Desain dan Metode. PT. Raja Grafindo Persada: Jakarta. 